\title{
The Greening of Work: How Green Is Green Enough?
}

\author{
I Timo Räikkönen
}

Researcher, Finnish Institute of Occupational Health, Finland

\begin{abstract}
Today's constantly deepening environmental problems have brought about the need to remold current work cultures along the lines of green thinking. However, profound differences still prevail between the different strands of green thought and practice with regard to the greening of work. The main purpose of this paper is to look in more detail at the arguments and implications of two differing positions, namely 'environmentalism' and 'ecologism'. The ideas of corporate social responsibility, green jobs, and downshifting are chosen as objects for closer scrutiny. A critical examination of these contemporary discourses leads to the conclusion that at least so far, they all remain within the confines of environmentalism: no radical changes are presupposed in the current ways of working or in our relationship with the non-human world. Viewed from the perspective of ecologism, the studied greening efforts remain too reformist and anthropocentric to be capable of making work truly 'green'.
\end{abstract}

\section{KEY WORDS}

corporate social responsibility / downshifting / ecologism / environmentalism / greening of work / green jobs

\section{Introduction}

he steady deterioration of environmental conditions and the depletion of natural resources have provided a marked impetus to begin transforming work along the lines of green thinking. In recent years, these different environmental strategies have included, for example, organizational changes (e.g. Docherty et al. 2009; Isles 2008; Ramus 2002; Senge et al. 2008; Zadek 2001), worker mobilization (Mayer 2008; Silverman 2006; UNEP 2007), green job programs (e.g. Jones 2008; Renner et al. 2008), and work-time reduction programs (e.g. Coote et al. 2010; Hayden 2000; Schor 2010). Three main subject areas are now to be considered when discussing the greening of work. The first is the greening of existing jobs (e.g. championing green initiatives at the workplace; providing opportunities for employees to participate in environmental work within companies). The second is the creation of new 'green-collar' jobs through environmental protection. The third is the extension of informal and subsistence work at the expense of formal wage labor by introducing, for example, more flexible work practices and employment time reduction policies. The underlying idea with this last approach is to provide the time needed for people to participate in the building of a more sustainable society and in the creation of new opportunities for simple living (e.g. Andrews and Urbanska 2010; Hayden 1999).

As planetary boundaries - i.e. the natural limits to humanity's use of the planet are closing in (e.g. Butchart et al. 2010; Monastersky 2009; Rockström et al. 2009), the necessity for the 'ecologization' of current work cultures becomes increasingly evident 
(Littig and Grießler 2005). However, this immediately begs the question: How green is green enough when it comes to the greening of work? We cannot seriously explore this question without a general framework within which the 'greenness' of these various greening efforts can be established with more clarity and detail. The main purpose of this paper is to present such a framework, and to demonstrate its use in practice.

The approach used in this paper is in many ways similar to that used by Kilbourne (1995), but applied in a different setting. Kilbourne (ibid.) set out to clarify the nature of green advertising with the purpose of demonstrating that the concept is far more complex than is normally suggested. As a result, he was able to bring into the advertising literature a 'clearer delineation of what an ecological perspective entails and how it is qualitatively different from an environmental perspective' (ibid., p. 7; see also Dobson 2000). In a similar vein, and based on relevant debates in environmental philosophy/ politics, sociology and organizational management, this paper sets out first to explore (on a conceptual level) the differences between these two types of green (i.e. environmentalism and ecologism) and how they relate to the greening of work. In the second part of the paper, this two-fold distinction will be used in practice to assess the green character of three prominent approaches to greening the work, namely corporate social responsibility, green jobs and downshifting.

It should be noted that the focus of this paper is on the wealthier industrialized countries and their institutions of work. The topic is especially relevant for the Nordic countries which have traditionally paid a great deal of attention to both the promotion of sustainable development and to the modernization of their working life institutions. However, at the same time, these countries still substantially exceed their environmental space (in the list of countries of over a million people with the largest ecological footprint, the Nordic countries, for example, all rank in the top 20) (WWF 2010). It is also known that these same countries will face the burden of cutting their greenhouse gas emissions by up to 95 percent by 2050 in order to avoid dangerous climate change (e.g. Hare 2009). For all wealthy industrialized countries, the need for wholesale economic restructuring is rapidly becoming more acute (e.g. Barbier 2009; Brown 2008; Friedman 2008). Thus current work practices must be also adjusted to meet the requirements of a general 'sustainability agenda' (e.g. Nielsen et al. 2010).

\section{Two-fold approach to the greening of work}

Before embarking on the main task of this paper, a brief excursion is in order to put the recent development in green thought into a historical perspective. The three major ecopolitical preoccupations that have developed over the last four decades can be identified in the themes of participation, survival, and emancipation (Eckersley 1992).

Early environmental activism and debates on the 'crisis of participation' gained marked prominence in the 1960 s along with the rise of the civil rights movement. No serious thought was given at the time to the notion that there may be ecological limits to growth that cannot be overcome by better planning and management (ibid., p. 8). Public concern over environmental problems was therefore widely interpreted as being concerned with only participatory and distributional issues (i.e. who gets to exercise power over nature, and on whose behalf) (ibid., p. 9). The 'limits to growth' debate of the 1970s had a significant impact on the rise of the survivalist perspective, which emphasized that 
the environmental crisis was, in essence, about the very survival of humanity rather than a mere management problem (Goldsmith et al. 1972; Meadows et al. 1972). The third, emancipatory phase of ecopolitical inquiry, which has been developing since the early 1980s, has tried to form a creative synthesis of the themes of participation and survival by focusing on a more encompassing theme, that of 'crisis of culture and character' (Eckersley 1992, p. 29). In contrast to the rather pessimistic views of the survivalists, emancipatory theorists have regarded the environmental crisis as also offering an opportunity for cultural renewal and moral development, that is, an opportunity to re-evaluate our place within the larger ecosystem (Roszak 1979).

A rather wide variety of environmental positions is to be found within the now mainstream emancipatory tradition, ranging from environmentalism to ecologism with multiple positions in between, such as resource conservation, human welfare ecology, and preservationism (cf. Eckersley 1992). For practical and heuristic reasons (see section 'The actual greenness of three contemporary approaches towards the greening of work'), this paper excludes these midrange positions within the emancipatory tradition and focuses only on the opposite ends of the continuum (environmentalism vs. ecologism).

In order to situate the environmentalist and ecologist positions properly within the emancipatory tradition, one needs to look more closely at these differing positions using two dimensions: the political and the positional (position of humans in nature) (cf. Kilbourne 1995). Within the political dimension, it is necessary to examine where these two positions lie in the reformist-radical continuum. As we see below, the environmentalist position considers reformist strategies sufficient for making work 'green', whereas the ecologist position argues for the need of a more paradigmatic change. The main question within the positional dimension revolves around the anthropocentric/ecocentric cleavage, that is, how these two positions perceive the role of humans vis-à-vis nature (cf. Eckersley 1992). This investigation will reveal that the proponents of environmentalism tend to see instrumental value in nature for purely human purposes, whereas the proponents of ecologism also value the non-human world for its own sake. The decision to focus solely on the opposite ends of the environmental continuum will also affect the nature of the literature used in the following analysis, that is, the selected literature will display scholarly relevance, with regard to two broad positions in particular: the 'reformist anthropocentric' and the 'radical ecocentric'. This will effectively exclude midrange positions from consideration, such as those of social ecologists who support political radicalism but only within the confines of anthropocentrism (e.g. Bookchin 1980).

\section{Environmentalism vs. Ecologism: political dimension}

While in agreement that some form of transition towards more sustainable or green work practices is needed, environmentalist strategies for actually making this happen can exist in very different forms. Within the environmentalist position, the preferred mode of critique is that of reformism, which includes a strong belief in so-called 'techno-fix' options that operate within the framework of the status quo (Dobson 2000; Kilbourne 1995). Reformist strategies typically focus on reducing the throughput of energy and materials in the economic system by advocating the so-called efficiency revolution. Social imagination is thus concentrated within this position primarily on the revision of means (i.e. new technology and planning) rather than on the revision of goals (Sachs 1995, p. 439). 
The ecologist position, on the other hand, questions the underlying assumptions of Western civilization and its values and argues for restructuring of global political and economic institutions along more ecological lines (Dobson 2000; Merchant 1992). To begin with, the proponents of this more radical ecology stance argue that the consumption of material goods by individuals in affluent industrial societies should be reduced if we are going to live within Earth's natural limits (Dobson 2000, p. 16). Secondly, they argue that the institution of a much lower level of economic activity, together with a much simpler and (materially) less affluent lifestyle could very well provide wider and more profound forms of fulfillment than that provided by the present consumer society (Baxter 1999, p. 197; see also Dobson 2000).

Within the context of work, the environmentalism position subscribes to the need to transcend the 'jobs versus environment' rhetoric towards the promotion of greener employment. The proponents of environmentalism thus view environmental protection as a welcomed opportunity for enhanced growth and job creation. Hence the notion of 'double dividend' is used to describe the situation in which environmental regulation stimulates investment and therefore employment within, for example, the emerging clean-technology industry (Crowley 1999). However, despite the willingness to move beyond making only superficial ecological improvements (i.e. from remedying ecological decline to actually greening industry), the proponents of environmentalism do not call into question the prevailing view of post-industrial society as a technological, affluent, service society (Crowley 1999; Kilbourne 1995). In contrast, the proponents of ecologism envisage a different kind of society. They strongly oppose, for example, the idea of a workless future, where automated production will enable people to concentrate most of their time on expanding services, greater leisure and (material) satisfaction (Dobson 2000). The idea of merely waiting for 'free handouts from the faceless world of technology' (Allaby and Bynyard 1980, p. 210) seems unattractive for the proponents of ecologism for a number of reasons, including the fact that this scenario fails to take account of the problems of sustainability on a finite planet. Another major point of critique against the workless future is that the proponents of ecologism consider work - but not necessarily in the form of paid employment - to be a necessity of the human condition, that is, something which uplifts the spirit, brings meaning to daily life, and even helps to create oneself (Roszak 1978; Porritt 1984; Dobson 2000).

As social concepts, environmentalism and ecologism also have differing views about the future of work organization. The proponents of environmentalism, as reformists, are inclined to support the dominant perspective on this issue, that is, that goods and services will be increasingly produced and delivered through employment (cf. Williams 2007). The proponents of ecologism, on the other hand, seek to expand this vision to include work beyond employment. From their perspective, formal employment has a tendency to promote open economies (cf. Williams 2007), whereas the development of informal work would be more in line with the overall desire for a more localized and self-reliant form of economic development (Dobson 2000). For the proponents of ecologism, the reasoning behind favoring more self-supporting and informal social and economic arrangements boils down to the notion that today's expanding economy has to constantly make up for the work it destroys (e.g. due to investments in labor-saving technology) by generating new jobs that are dependent on 'opening up massive new markets by stimulating wants and wasteful appetites' (Roszak 1978, p. 233). The works of people like Roszak (1978) and Taylor (1991) recognize the risks involved with these 
kinds of employment opportunities in terms of loss of responsibility and personal engagement. Taylor (ibid.), for example, has attempted to demonstrate how our current society is prone to foster radical anthropocentrism, that is, how it makes us take an instrumental stance to all facets of our life and surroundings, to nature and to our social arrangements (pp. 58-59). It has thus been suggested that the prevailing attitude toward nature has been transformed 'from one of reverence and harmony to one of exploitation and domination' (Kilbourne 1995, p. 11). The proponents of environmentalism maintain the position that technological advancements and legislative action will suffice to safeguard the environment and our future in it, whereas the proponents of ecologism also argue for a more fundamental cultural change (i.e. a shift away from the dominant social paradigm and toward a more ecologically based world view) (Kilbourne 1995, p. 12). This anthropocentric/ecocentric cleavage that divides these two positions will be dealt with more closely below.

\section{Environmentalism vs. Ecologism: positional dimension}

Sharp political differences aside, the environmentalist position and the ecologist position both have their own philosophically consistent views of nature's value, and these views will put them at the opposite ends of the anthropocentric-ecocentric continuum. The proponents of environmentalism subscribe to the dominant social paradigm stemming from Enlightenment thinking, which assumes the supremacy of humans over non-human entities (Kilbourne 1995). The more radical green thinking adhered to by the proponents of ecologism, on the other hand, suggests that the non-human nature constitutes a source of independent value. This view can be dissected into two different strands: one is the idea that there is an intrinsic value to non-human nature, and the second is the notion that the human-centered (or anthropocentric) view of the world should be rejected (Bromley 2004, p. 99). The proponents of ecologism are thus convinced that a much more humble and humane approach of harmony with ecological processes is needed than that acknowledged by the more moderate, anthropocentrically minded environmentalists (e.g. O’Riordan 1981).

On the whole, the proponents of environmentalism tend to be more pragmatic than their ecocentric counterparts in their willingness to 'seek a balance among goods, environmental or otherwise, insofar as all goods are weighed on the scales of human interest' (Whiteside 2002, p. 10). The proponents of ecologism remain suspect that this kind of process of balancing values leaves environmental goods too vulnerable to continued exploitation, and that the only viable solution is to replace anthropocentrism with a more encompassing ecocentric ethic (ibid., p. 10; see also Eckersley 1992). The notion of the need for this kind of sweeping ethical re-assessment has been strongly criticized by the moderate or 'enlightened' anthropocentrists, who hold that 'one does not need to appreciate or value the non-human in order to recognize that humans, in virtually everything they do, are dependent upon the natural world' (Wells and Lynch 2000, p. 35; see also Norton 1991, p. 226). The moderately anthropocentric environmentalist position thus argues for a more gradualist, or reformist strategy with the aim of heightening awareness that 'it serves no one's interest to (over-)exploit natural resources or treat other beings cruelly or inhumanely' (Hayward 1995, p. 62). Another point of critique against the pursuit of an ecocentric ethic is the fact that man's conscious actions are anthropocentric 
by definition (Williams 1992). In other words, any ethic is a human construction, even if it is formulated with no hint of self-interest (Wells and Lynch 2000, p. 29). However, the proponents of ecologism are themselves willing to admit that the pursuit of an ecocentric environmental ethic will always be at least weakly anthropocentric (Dobson 2000, p. 55). Smith (1998) sums up this question well by stating: 'The question, then, is not how we escape human valuation but whether it is possible to think of ways in which the value of natural things is not subordinate to the way they gratify the consumption patterns of human beings' (p. 5).

What, then, are the implications of this anthropocentric/ecocentric debate with regard to the greening of work? One way to approach this question is to consider the challenge of cultivating environmental awareness and responsibility in today's work society. To begin with, the latest discussions on the world of work show that the puritan work ethic is still very much alive (e.g. Donkin 2010). In addition to this, the concept of work has been rather successfully reified (at least within the advanced Western economies), which means that work is still mainly viewed as a 'job' that is done for an employer for pay. From the perspective of ecologism, ecocentric ethics could be seen as a counterforce to the dominance of such a work ethic that at the moment allows workers to effectively deny responsibility for what they do at work. In other words, if workers feel that they are already doing their part as productive members of society, there is no incentive for them to begin asking questions at a deeper level, such as 'Is this job honest and useful?' or 'Is it a real contribution to the human and non-human need?' (cf. Roszak 1978, p. 220). The proponents of environmentalism, on the other hand, would likely argue that there is no need to go as far as cultivating strictly ecocentric ethics in order to strengthen the role of environmental attitudes in everyday work and life. Instead, they would prefer a more moderate, anthropocentric solution to this challenge that is based on the belief that 'if humans get clear enough about their own best interests, then they will realize that these coincide with the interests of the rest of nature' (Hayward 1995, p. 63).

It can be concluded, then, that the politically radical and ecocentric nature of the ecologism position sets it clearly apart from the more mainstream environmentalism position. The proponents of ecologism are keen to push for a profound change in the dominant social paradigm and to question the notion of human supremacy over nature. The proponents of environmentalism, on the other hand, remain content with the current political, economic and social practices. These 'anthropocentric environmentalists' are also unlikely to argue for the intrinsic value of the non-human environment, or to be convinced of the need to readjust their anthropocentric view of the world in any significant way.

\section{The actual greenness of three contemporary approaches towards the greening of work}

Based on this discussion, we have now gained a better understanding of some of the major differences - both political and positional - between the environmentalist position and the ecologist position. Other well-established distinctions could also be used in a broadly similar way to describe these differing positions, such as 'shallow green' vs. 'deep green' (cf. Naess 1995), or 'weak sustainability’ vs. 'strong sustainability’ (cf. Pearce et al. 
1989). However, for the remaining discussion about the 'greenness' of current developments in work life, Dobson's (2000) well-known distinction between 'environmentalism' and 'ecologism' seems to be the most descriptive (i.e. both the political and the positional dimension are included here). As was mentioned at the beginning of the paper, Kilbourne (1995) has examined the relationship between ecology and advertising with an approach that is based on this particular distinction between environmentalism and ecologism. In fact, in order to clarify the nature of green advertising, he used five different types of green which were (from least to most political and human positional): environmentalism, conservationism, human welfare ecology, preservationism, and ecologism (Kilbourne 1995; see also Eckersley 1992). Even though Kilbourne's classification highlights the fact that, in reality, there is a whole spectrum of positions between environmentalism and ecologism, it appears to be a somewhat too detailed approach to be used as a fully operational conceptual device (i.e. it is difficult to find real-life examples that fall clearly into just one of these categories). For practical and heuristic reasons, then, and to avoid some of the problems that can be expected with such a comprehensive level of detail, a two-fold distinction (environmentalism vs. ecologism) will be used below to examine the green character of three separate approaches, namely corporate social responsibility, green-collar jobs and downshifting. These particular approaches were chosen as prominent representatives of the three main subject areas that need to be considered when discussing the greening of work (i.e. the greening of existing jobs, the creation of new 'green-collar' jobs by environmental protection, and the extension of informal and subsistence work at the expense of formal wage labor). The purpose, however, is not to compare one approach against another, but rather to provide more insight into the 'greenness' of each of these greening efforts with the help of the created framework. As a result, instead of providing an exhaustive account of the three approaches under scrutiny, the focus will simply be on trying to place these approaches correctly within the proposed political and positional scales.

\section{Corporate social responsibility}

Corporate social responsibility (CSR) represents the first of three subject areas concerning the greening of work, that is, the greening of existing jobs. In short, CSR can be described as 'a concept whereby companies integrate social and environmental concerns in their business operations and in their interaction with their stakeholders on a voluntary basis' (EC 2001, p. 6). What started as an effort by various charities and non-governmental organizations to push CSR higher up the corporate agenda has now evolved into a flourishing profession and an industry in its own right, with its physical manifestations such as education programs, business school chairs, professional organizations and journals (Crook 2005; Kallio 2006). The conceptions of CSR have been fundamentally impacted, for example, by the Brundtland Report of 1987 (Dobers and Springett 2010). As a core response of global business to the need to promote sustainable development, CSR thus rests on three well-known pillars: economic growth, ecological balance, and social progress (Clapp and Dauvergne 2005, p. 225). From an environmental perspective, CSR activities have particularly included the use of 'environmentally friendly' technologies, and pursuit of higher levels of environmental performance through recycling and pollution abatement (e.g. McWilliams et al. 2006). 
Ehrenfeld (2008) has argued that business - as the most powerful global institution in terms of financial power, and as the largest employer - should be a key target for institutional change regarding sustainability (i.e. for making work more green). He also anticipates that if businesses begin to operate with a new set of sustainability beliefs and norms, their employees are likely to express and practice these new views in other life areas (ibid., p. 200). The adoption of well-crafted CSR programs could therefore be used, for their part, to transform some of the more outdated work-related practices and attitudes towards more sustainable ones as part of the overall 'sustainability transition'.

What then, is the proper place for CSR within the two-fold distinction between environmentalism and ecologism? To begin with the political dimension, Jallow (2009) has interestingly demonstrated that radicalism and CSR are not necessarily exclusive concepts, but that in the present situation the reformists have 'claimed' the CSR debate and therefore disempowered those who would bring about more fundamental changes (p. 321). As Kallio (2006, p. 173) observes, the CSR discourse has, either explicitly or implicitly, silenced the most sensitive topics that could threaten its own legitimacy, such as continuous economic growth. In a similar vein, Valor (2005) has described how the discourse of CSR has largely been turned into PR exercises rather than endeavoring to rethink and reshape corporate internal management in any serious way. This kind of 'managerial capture' has led to a situation in which 'social and environmental performances are not seen as an end in themselves but as a source of competitive advantage or a condition to be competitive' (ibid., p. 199). Empirical evidence also suggests that even in companies that are positioned highly in terms of greenness, the principal motivation for going green has usually been stakeholder pressure, government legislation, and the opportunity to enhance the corporate image (Saha and Darnton 2005). Thus, CSR practices clearly appear to be more reformist than radical in nature (i.e. the emphasis is clearly on improving environmental performance rather than on pursuing more profound structural or attitudinal changes).

With regard to the positional dimension, there seems to be little or no discussion in the field of CSR of the possible need to shift the balance from anthropocentrism to ecocentrism. In other words, even though CSR practitioners and advocates are beginning to take a more active role in environmental protection, the ecocentric logic is still alien to the majority of them (Pina e Cunha et al. 2008). This becomes evident if we look, for example, at the apparent lack of progress on the research and practice of 'ecocentric management', a concept that was originally coined by Shrivastava already in the mid1990s (Pina e Cunha et al. 2008; Shrivastava 1995). The proponents of the ecocentric management paradigm, in which organizations seek to establish more harmonious relationships between their natural and social environments, have so far failed to establish any stronghold in the field of CSR. At the present stage of development, CSR thus appears to be green only in the weakest sense (environmentalism).

\section{Green-collar jobs}

The second important subject area concerning the greening of work is the creation of new green jobs, or green-collar jobs, through environmental protection. In a landmark study on the impact of an emerging global 'green economy' in the world of work (Renner et al. 2008), green jobs were defined as 'work in agricultural, manufacturing, 
research and development $(\mathrm{R} \& \mathrm{D})$, administrative, and service activities that contribute substantially to preserving or restoring environmental quality'. According to Jones (2008), today's green-collar workers are those who install solar panels, retrofit buildings to make them more efficient, refine waste oil into biodiesel, and construct transit lanes, etc. (p. 13). The transition to a sustainable, low-carbon economy will be a mixture of technological innovations, shifts in business and investment strategies, and a new set of policies that will involve businesses, workers, communities, and movements (Renner et al. 2008, p. 277). Trade unions in particular have been at the forefront of the discussions on green jobs creation with the aim of ensuring that job loss as a result of environmental transition is minimized, and that the inevitable shifts in employment patterns and skill profiles do not occur at the expense of decent work and decent terms and conditions (e.g. TUC 2008).

The mainstream green jobs discourse does not seem to fit easily within either the environmentalist or the ecologist position. The language used in the joint ILO/UNEP/ ITUC/IOE report on green jobs (Renner et al. 2008), for example, reflects a rather ambiguous mindset on many key issues. On the one hand, the report discusses (in line with the ecologist position) the possible importance of work time reduction programs in order to share available work better, and the possibility that a sustainable economy might need a new economic theory that abandons the outdated assumption that quantitative growth is unconditionally desirable (Renner et al. 2008, p. 83).

On the other hand, the report seems to approach the greening of work mostly as a series of investments and technological innovations (i.e. promoting renewable energy sources and replacing inefficient machinery, equipment, buildings, and vehicles with more efficient models) (Renner et al. 2008, p. 83; see also Deitche 2010; Llewellyn et al. 2008). Thus, despite some concessions made towards the ecologist position, the ideas presented in the report are clearly more politically reformist than radically transformative. Another joint report on green jobs, prepared by the Center on Wisconsin Strategy, the Workforce Alliance, and the Apollo Alliance (White and Walsh 2008), draws broadly similar conclusions, while suggesting that the common aim of business leaders and trade unions is to save jobs and create new ones by focusing principally on investments in innovation, new technology and energy efficiency (see also Canadian Labor Congress 2000). In a similar vein, Jones, the author of the influential book 'The Green-Collar Economy' (2008), argues that at this stage, making 'maximum demands', such as directly challenging the paradigm of growth and consumption, would only create more resistance than support. Instead, he would prefer making only 'minimal demands', that is, to use more 'family friendly eco-populism' that can mobilize and unite large amounts of people who would otherwise be turned off by a more extreme set of demands (ibid., p. 93).

With regard to the human positional scale, we already saw that green jobs are defined as jobs that should contribute substantially to preserving or restoring environmental quality. Although this sounds promising from the perspective of the ecologist position, the green jobs discourse nevertheless appears to be rather closely tied to 'nature as resource' and management efficiency (e.g. Llewellyn et al. 2008; Renner et al. 2008; TUC 2008). However, there is at least one notable exception that explicitly states an intrinsic value motivation. Jones (2008) has argued that the transition towards an inclusive, green economy rests on three transformative principles: equal protection for all, equal opportunity for all, and reverence for all creation. From the perspective of the ecologism position, the third principle is especially interesting, because it states that 
'our commitment must be deeper than a desire merely to maximize the utility of other living beings and ecosystems for our own desires and pursuits' (ibid., p. 75).

Overall, then, the green jobs discourse is able to transcend, at times, the environmentalist position on both the political and positional scale. However, it still fails to qualify as a member of the ecologist position. This is mainly because the ecological crisis is still approached within this discourse largely as a management problem (albeit a severe one) that can be solved within the dominant social paradigm, that is, without any major political, social or 'metaphysical' transformation.

\section{Downshifting}

The third subject area concerning the greening of work covers all the issues and phenomena that strive to strengthen the role of more self-supporting and informal social and economic arrangements at the expense of formal wage labor. Downshifting is one such phenomenon that has gained popularity in recent years - especially within the wealthy western world - as an alternative to today's frenetic work and consumptionorientated lifestyle (Andrews and Urbanska 2010; Chhetri et al. 2009a). In short, downshifting is about working less, spending less, and doing things differently (e.g. Juniu 2000). Or, to be more precise, it can be understood as a 'long term change in lifestyle other than planned retirement, which has been accompanied by the earning of less money' (Chhetri et al. 2009b, p. 349). The concepts of 'voluntary simplicity', 'sea change' and 'downshifting' are often used interchangeably in the literature, and despite subtle differences, they all suggest a voluntary simplification of lifestyle in order to achieve an improvement in the quality of life (Chhetri et al. 2009b; see also Etzioni 1998). Available evidence also suggests that attitudes towards the environment may influence the decision to downshift (e.g. Leonard-Barton 1981; Shama and Wisenblit 1984; Iwata 1997).

To explain the different motivations underlying voluntary simplicity behaviors, Leonard-Barton (1981), for example, has come up with a typology consisting of three types of individuals, namely 'conservers', 'crusaders', and 'conformists'. Conservers consider frugality a way of life that above all makes economic sense, whereas for crusaders, the motivation to engage in voluntary simplicity behaviors is born of a strong sense of social responsibility (i.e. a concern for the world's dwindling resources) (Leonard-Barton 1981, p. 248). Conformists, on the other hand, dutifully recycle resources, cut down on meat consumption, etc., mostly because they are just following the example set by their more environmentally minded neighbors in the community (ibid.). More recently, Chhetri et al. (2009b) set out to explore the characteristics of downshifters in more detail and found that, for the participants in their case study, the most important reasons to downshift were the need to gain additional time with the family, improved control over one's life, and greater fulfillment. Somewhat surprisingly, then, only a small minority of those who had chosen to downshift could be labeled as 'ecocentric downshifters' who hold pro-environmental attitudes and express a desire to live a less materialistic lifestyle (ibid.).

More research is therefore clearly needed for assessing the actual level of commitment of downshifters to the tenets of voluntary simplicity (cf. Chhetri et al. 2009a), but for now, it is safe to assume that in today's society there might be more pressing (e.g. 
health- and family-related) reasons for people to jump off the 'frenetic work treadmill' than the pursuit of a truly ecocentric way of life. On the positional scale, then, the proper place for downshifters remains to be determined. Similar difficulties can be encountered when trying to pinpoint downshifters on the political scale. On the one hand, downshifting represents a promising possibility - especially from the perspective of the ecologism position - of the revival of the informal economy in which people work for themselves and one another, on tasks that are valuable to themselves (cf. Robertson 1983). As Hayden (1999) points out, 'the more time free from employment, the more energy people can devote to these alternatives outside the global market', and 'the more developed these alternatives, the less dependent people will be on employment in the market to meet their needs' (p. 54). On the other hand, it can be argued that, despite all its radical potential, downshifting represents in reality a rather moderate form of voluntarily simplicity. In other words, downshifting is being practiced for the most part by economically well off and secure people who 'voluntarily give up some consumer goods (often considered luxuries) they could readily afford, but basically maintain their rather rich and consumption-oriented lifestyle' (Etzioni 1998, p. 622). It can be concluded, then, that as an emerging work life phenomenon, downshifting clearly has the potential to shift the balance from the environmentalism position towards the ecologism position. Available evidence suggests, however, that this potential has not yet been fully realized in practice (e.g. Chhetri et al. 2009b; Twenge 2010).

\section{Discussion}

This paper's overview on the different tenets and beliefs of two differing green positions revealed that the proponents of ecologism are clearly more willing to 'push the envelope' beyond what the more moderate environmentalists would consider to be the most feasible and attainable course of action for dealing with our current environmental problems. However, it can be argued that these positions could also have a lot to learn from each other. For one thing, the proponents of ecologism could learn from their more pragmatic counterparts not to allow their 'utopian aspirations' to settle as mere mental compensation for the shortcomings of the status quo (cf. Eckersley 1992). Instead, they should strive to connect their aspirations more closely with an understanding of existing power relations and forces for change (cf. Hayward 1994). From this perspective, the proponents of ecologism should pay heed to André Gorz's advice (which was originally given to the ecological Left):

'We have to start out from what work is and what work really means today in order to transform it, reduce it and expand the scope for autonomous activities, production for one's own use, and self-realization for every-one' (Gorz 1994, p. 64).

In contrast, the proponents of environmentalism could learn about their counterparts' willingness to 'venture beyond the given' and to question the taken-for-granted nature of the present (cf. Eckersley 1992, p. 186). The proponents of environmentalism may also start feeling pressure to reflect their chosen gradualist and reformist environmental strategy in light of the fact that the 'planetary boundaries' are already closing in (e.g. Rockström et al. 2009). This means, for example, that it is becoming more and more 
difficult to wait for the more time-consuming processes, such as the cultivation of environmental awareness and responsibility, to play out. Hence needs are emerging to learn 'the art of rapid transition' (cf. Boyle and Simms 2010). Compelling reasons thus exist for the proponents of environmentalism to start making more 'maximum demands' (cf. Jones 2008), despite the risk that in the process, people may be turned off by asking too much of them too fast.

One of the most pressing questions for further research relates to the challenge of how to introduce these transitory demands (whether reformist or radical) without creating too much resistance among the affected workers and their unions. To begin with, it can be expected that workers' tasks and performances are easily influenced by environmental improvements: by efforts to use resources more economically or to substitute polluting chemicals with more ecological alternatives (Hvid and Lund 2002, p. 9). Secondly, some existing jobs may even disappear if a company decides to give up the manufacture of its existing products and focus upon more environmentally benign ones (ibid., p. 9). From this perspective, it would be interesting to look more closely at whether a concept such as 'just transition' could provide a joint platform for all the greening efforts (i.e. in a way that would bring the proponents of environmentalism and ecologism closer together). 'Just transition' is an emerging concept, promoted especially by trade unions, that recognizes that support for environmental policies depends on a fair distribution of the costs and benefits of those policies across the economy (e.g. TUC 2008; Renner et al. 2008). Within the context of work, different kinds of 'just transition strategies' could thus be utilized to reassure workers that the burdens of the change will be shared as equally as possible, and that there will also be support for re-educating and re-training those affected by the transitional measures (cf. TUC 2008).

One of the concerns for workers and trade unions is also the fact that some new green jobs, such as recycling work, seem to involve serious occupational health hazards (Renner et al. 2009; TUC 2008). On that note, there clearly exists a window of opportunity for the formation of larger 'blue-green coalitions' between labor and environmentalist groups around the need to reduce the risks of community and workplace exposures (Mayer 2009). According to Mayer (ibid., p. 192), these blue-green coalitions are the ideal forum in which a common agenda can be developed to promote both healthy jobs and a clean environment. In a similar way, just transition advocates, such as the Blue Green Alliance in the United States, have attempted to bypass industry's 'jobs vs. environment' framing by proposing so-called superfunds for workers displaced by environmental regulation (e.g. Gould et al. 2004; Young 2003). These funds, generated through taxes on pollution, would offer, for example, wage replacement, training and educational benefits, health insurance, and retirement contributions (Young 2003). From a Nordic perspective, it is also interesting to note how the just transition approach overlaps with the central principle of the 'flexicurity approach' that posits how 'workers need income, employment, and labor security rather than a particular job in a particular industry with a particular employer' (Renner et al. 2009, p. 291; see also Wilthagen and Tros 2004). As Renner et al. (ibid.) observe, the flexicurity approach - a model developed with success by Scandinavian countries, and now a key element of the European Employment Strategy - may very well facilitate the effort to develop a 'Just Transition', at least within the European context. 


\section{Conclusion}

The elastic nature of the label Green has necessitated green thinkers to create more effective ways to distinguish between different types of green (e.g. Dobson 2000; Naess 1995; Pearce et al. 1989). This is also true within the context of work, especially now, given the widespread awareness of the need to start transforming work along the lines of green thinking. This paper set out to show that rather profound differences still exist between different strands of green thought and practice that should be recognized more clearly when thinking about the greening of work. The dichotomy between environmentalism and ecologism, as presented in this paper, represents one viable approach for assessing the 'greenness' of current developments in work life with more clarity. However, it is also worth mentioning that there are interesting and rather ambitious discussions emerging that, for example, strive to altogether transcend the anthropocentrism-ecocentrism duality that has so far characterized environmental debates, especially in the English-speaking world (Esbjörn-Hargens and Zimmerman 2009; Whiteside 2002). Thus, the aim here is to develop more integral approaches to environmental concerns that would be able to better appreciate the strengths of many approaches and methods while at the same time exposing their respective limits and blind spots (Esbjörn-Hargens and Zimmerman 2009). This paper, however, proceeded perhaps from a more modest premise that if we continue to use terms such as 'environmental' and 'ecological' interchangeably and without meaningful distinction, this could effectively prevent us from recognizing and realizing other possibilities and choices that might be needed to make work truly 'green'. The conceptual framework created in this paper is able to make these distinctions more visible, as became evident when it was applied to three contemporary approaches to greening the work; at least so far, the discourses on CSR, green jobs and downshifting all remain too reformist and anthropocentric in nature to qualify as members of the ecologist position. They thus belong more appropriately to the environmentalist position, which does not presuppose any radical changes in our relationship with the non-human natural world, or in our mode of social and political life.

Examples abound, then, of 'reformist anthropocentric' approaches to greening the work. At the same time, however, the virtual absence of more 'radical ecocentric' greening efforts raises the uncomfortable question of whether we are approaching the challenge of greening the work in the manner of the fabled drunkard 'who lost the car keys but kept looking for them under the street lamp because that is where the light was' (cf. Ehrenfeld 2008).

\section{References:}

Allaby, M., and Bunyard, P. (1980) The Politics of Self-sufficiency. Oxford: Oxford University Press.

Andrews, C., and Urbanska, W. (2010) Inspiring People to See That Less is More. In State of the World: Transforming Cultures, from Consumerism to Sustainability (pp. 178-184). New York: W. W. Norton.

Barbier, E. B. (2009) A Global Green New Deal. New York: United Nations Environment Program (UNEP).

Baxter, B. (1999) Ecologism. An Introduction. Edinburgh: Edinburgh University Press. 
Boyle, D., and Simms, A. (Eds.) (2010) The Art of Rapid Transition How to thrive in times of crisis. London: New Economics Foundation. Available at www.neweconomics.org/ publications/the-art-of-rapid-transition.

Bookchin, M. (1980) Toward an Ecological Society. Montreal: Black Rose Books.

Bromley, S. (2004) Political ideologies and the Environment. In D. Goldblatt (Ed.), Knowledge and the Social Sciences: Theory, Method, Practice. Second Edition (pp. 77-118). London: Routledge.

Brown, L. R. (2008) Plan B 3.0 Mobilising to Save Civilization. New York: Earth Policy Institute.

Butchart, S. H. M. et al. (2010) 'Global Biodiversity: Indicators of Recent Declines', Science 328: 1164-1168. DOI: 10.1126/science.1187512.

Canadian Labor Congress (2000) Just Transition for Workers During Environmental Change. Canada: Canadian Labor Congress, April, 2000.

Chhetri, P., Khan, A., Stimson, R., and Western, J. (2009a) 'Why bother to downshift? The characteristics and satisfaction of downshifters in the Brisbane-South East Queensland Region, Australia', Journal of Population Research, 26(1): 51-72. DOI: 10.1007/s12546008-9005-y.

Chhetri, P., Stimson, R. J., and Western, J. (2009b) 'Understanding the Downshifting

Phenomenon: A Case of South East Queensland, Australia', Australian Journal of Social Issues, 44(4): 345-362.

Clapp. J., and Dauvergne, P. (2000) Paths to a Green World. The Political Economy of the Global Environment. Cambridge, MA: MIT Press.

Coote, A., Franklin, J., and Simms, A. (2010) 21 hours. Why a shorter working week can help us all to flourish in the 21st century. London: New Economics Foundation. Available at www.neweconomics.org/publications/21-hours.

Crook, C. (2005) 'The Good Company', Economist (January 22nd): 3-4.

Crowley, K. (1999) 'Jobs and environment: the 'double dividend' of ecological modernisation?', International Journal of Social Economics, 26(7/8/9): 1013-1027. DOI: $10.1108 / 03068299910245787$

Deitche, S. M. (2010) Green collar jobs: Environmental careers for the $21^{\text {st }}$ century. Santa Barbara, Calif: Praeger.

Dobers, P., and Springett, D. (2010) 'Corporate Social Responsibility: Discourse, Narratives and Communication', Corporate Social Responsibility and Environmental Management, 17: 63-69. DOI: 10.1002/csr.231

Dobson, A. (2000) Green Political Thought. Third Edition. London: Routledge.

Docherty, P., Kira, M., and Shani, A. B. (Eds.) (2009) Creating Sustainable Work Systems. Developing Social Sustainability. Second Edition. London: Routledge.

Donkin, R. (2010) The Future of Work. Houndmills: Palgrave Macmillan.

Eckersley, R. (1992) Environmentalism and Political Theory. Toward an Ecocentric Approach. London: UCL Press.

Ehrenfeld, J. R. (2008) Sustainability by Design. New Haven: Yale University Press.

Esbjörn-Hargens, S., and Zimmerman, M. E. (2009) Integral Ecology. Uniting Multiple Perspectives on the Natural World. Boston: Integral Books.

Etzioni, A. (1998) 'Voluntary Simplicity: Characterization, Select Psychological Implications, and Societal Consequences', Journal of Economic Psychology, 19: 619-643.

European Commission (EC) (2001) Green paper - Promoting a European Framework for Corporate Social Responsibility. COM (2001) 366 final, Brussels: EC, 18 July.

Friedman, T. L. (2008) Hot, Flat and Crowded. London: Allen Lane.

Goldsmith, E., Allen, R., Allaby, M., Davoll, J., and Lawrence, S. (1972) Blueprint for Survival. Boston: Houghton Mifflin.

Gorz, A. (1994) Capitalism, Socialism, Ecology. London: Verso. 
Gould, K. A., Lewis, T. L., and Roberts, J. T. (2004) 'Blue-Green Coalitions: Constraints and possibilities in the post 9-11 political environment', Journal of World-Systems Research, X, I, Winter 2004: 91-116.

Hare, W. L. (2009) A Safe Landing for the Climate. In State of the World: Into a Warming World (pp. 13-29). New York: W. W. Norton.

Hayden, A. (1999) Sharing the Work, Sparing the Planet. Work time, Consumption, and Ecology. London: Zed Books.

Hayward, T. (1994) Ecological Thought. An Introduction. Cambridge: Polity Press.

Hvid, H., and Lund, H. L. (2002) 'Sustainable Work. Concepts and Elements of Practice', The Journal of Transdisciplinary Environmental Studies, 1(2): 1-20.

Isles, N. (2008) Greening Work. London: The Work Foundation. Available at www.theworkfoundation.com/research/publications/publicationdetail.aspx?oItemId=196

Iwata, O. (1997) 'Attitudinal and behavioural correlates of voluntary simplicity lifestyles', Social Behaviour and Personality, 25(3): 233-240.

Jallow, K. (2009) 'Radicalism and corporate social responsibility: unlikely partners?', Management of Environmental Quality: An International Journal, 20(3): 321-334. DOI: 10.1108/14777830910950711

Jones, V. (2008) The Green Collar Economy. How One Solution Can fix Our Two Biggest Problems. New York: HarperOne.

Juniu, S. (2000) 'Downshifting: Regaining the Essence of Leisure', Journal of Leisure Research, 32(1): 69-73.

Kallio, T. J. (2006) 'Taboos in Corporate Social Responsibility Discourse', Journal of Business Ethics, 74: 165-175. DOI: 10.1007/s10551-006-9227-x

Kilbourne, W. E. (1995) 'Green Advertising: Salvation or Oxymoron?', Journal of Advertising, 24(2): 7-19.

Leonard-Barton, D. (1981) 'Voluntary simplicity lifestyles and energy conservation', Journal of Consumer Behaviour, 8(3): 243-244.

Littig, B., and Grießler, E. (2005) 'Social sustainability: a catchword between political pragmatism and social theory', Int. J. Sustainable Development, 8(1/2): 65-79.

Llewellyn, A. B., Hendrix, J. P., and Golden, K. C. (2008) Green Jobs: a guide to eco-friendly employment. Avon, Mass.: Adams Media Corp.

Mayer, B. (2008) Blue-Green Coalitions: Fighting for Safe Workplaces and Healthy Communities. Cornell: Cornell University Press.

McWilliams, A., Siegel, D. S., and Wright, P. M. (2006) 'Guest Editors’ Introduction.

Corporate Social Responsibility: Strategic Implications', Journal of Management Studies, 43(1): 1-18. DOI: $10.1111 /$ j.1467-6486.2006.00580.x

Meadows, D. H., Meadows, D. L., Randers, J., and Behrens, W. W. (1972) The Limits to Growth: A Report for the Club of Rome's Project on the Predicament of Mankind. New York: Universe.

Merchant, C. (1992) Radical Ecology. The search for a livable world. New York: Routledge.

Monastersky, R. (2009) 'A Burden Beyond Bearing', Nature 458: 1091-1094. DOI: 10.1038/4581091a

Naess, A. (1995) The Shallow and the Deep, Long-Range Ecology Movements: A Summary. In G. Sessions (Ed.), Deep Ecology for the 21 ${ }^{\text {st }}$ Century: Readings on the philosophy and practice of the new environmentalism (pp. 151-155). Boston: Shambhala Publications.

Nielsen, K. A., Elling, B., Figueroa, M., and Jelsøe, E. (Eds.) (2010) A New Agenda for Sustainability. Farnham: Ashgate.

Norton, B. G. (1991) Toward Unity Among Environmentalists. Oxford: Oxford University Press.

O’Riordan, T. (1981) Environmentalism. London: Pion Limited. 
Pearce, D. W., Markandya, A., and Barbier, E. (1989) Blueprint for a Green Economy. London: Earthscan.

Pina e Cunha, M., Rego, A., and Vieira da Cunha, J. (2008) 'Ecocentric management: An Update', Corporate Social Responsibility and Environmental Management, 15(6): 311-321. DOI: $10.1002 / \mathrm{csr} .169$

Porritt, J. (1984) Seeing green: the politics of ecology explained. Oxford: Blackwell.

Ramus, C. A. (2002) 'Encouraging innovative environmental actions: what companies and managers must do', Journal of World Business, 37: 151-164. DOI: 10.1016/S10909516(02)00074-3

Renner, M., Sweeney, S., and Kubit, J. (2008) Green Jobs: Towards Decent Work in a Sustainable, Low-Carbon World. New York: UNEP/ILO/IOE/ITUC.

Renner, M., Sweeney, S., and Kubit, J. (2009) Employment in a Low-Carbon World. In State of the World: Into a Warming World (pp. 115-118). New York: W. W. Norton.

Robertson, J. (1983) The Sane Alternative: a choice of futures. Available at www.jamesrobertson.com/books.htm\#sane

Rockström et al. (2009) 'A safe operating space for humanity', Nature 461: 472-475. DOI: $10.1038 / 461472 \mathrm{a}$

Roszak, T. (1979) Person/Planet. The Creative Disintegration of Industrial Society. London: Victor Gollancz.

Sachs, W. (1995) Global Ecology and the Shadow of 'Development'. In G. Sessions (Ed.), Deep Ecology for the 21 $1^{\text {st }}$ Century: Readings on the philosophy and practice of the new environmentalism (pp. 428-444). Boston: Shambhala Publications.

Saha, M., and Darnton, G. (2005) 'Green Companies or Green Con-panies: Are Companies Really Green, or are they Pretending to Be?', Business and Society Review, 110(2): 117-157.

Schor, J. (2010) Sustainable Work Schedules for All. In State of the World: Transforming Cultures, from Consumerism to Sustainability (pp. 91-95). New York: W. W. Norton.

Senge, P., Smith, B., Kruschwitz, N., Laur, J., and Schley, S. (2009) The Necessary Revolution. New York: Doubleday.

Shama, A., and Wisenblit, J. (1984) 'Value of simplicity: Lifestyles and motivation', Psychological Reports, 55: 231-240.

Shrivastava, P. (1995) 'Ecocentric management for a Risk Society', The Academy of Management Review, 20(1): 118-137.

Silverman, V. (2006) 'Green Unions in a Grey World. Labor Environmentalism and International Institutions', Organization and Environment, 19(2): 191-213. DOI: 10.1177/ 1086026606288780

Smith, M. J. (1998) Ecologism. Towards Ecological Citizenship. Buckingham: Open University Press.

Taylor, C. (1991) The Ethics of Authenticity. Cambridge: Harvard University Press.

Trades Union Congress (TUC) (2008) A green and fair future, for a just transition to a low carbon economy. London: Touchstone.

Twenge, J. M. (2010) 'A review of the empirical evidence on generational differences in work attitudes', Journal of Business and Psychology, 25(2): 201-210. DOI: 10.1007/s10869010-9165-6

UNEP (2007) Labour and the Environment: A Natural Synergy. Nairobi: United Nations Environment Program.

Valor, C. (2005) 'Corporate Social Responsibility and Corporate Citizenship: Towards Corporate Accountability', Business and Society Review, 110(2): 191-212. DOI: 10.1111/ j.0045-3609.2005.00011.x

Wells, D., and Lynch, T. (2000) The Political Ecologist. Hants: Ashgate.

White, S., and Walsh, J. (2008) Greener Pathways: Job and Workforce Development in the Clean Energy Economy. Madison, WI: Center on Wisconsin Strategy. 
Whiteside, K. (2002) Divided Natures: French Contributions to Political Ecology. Cambridge, MA: MIT Press.

Williams, B. (1992) Must a Concern for the Environment be Centred on Human Beings? In C. C. W. Taylor (Ed.), Ethics and the Environment (pp. 46-52). Oxford: Corpus Christi College.

Williams, C. C. (2007) Rethinking the Future of Work. Directions and Visions. Basingstoke: Palgrave Macmillan.

Wilthagen, T., and Tros, F. (2004) 'The concept of 'flexicurity': a new approach to regulating employment and labour markets', Transfer: European Review of Labour and Research, 10(2): 166-186. DOI: 10.1177/102425890401000204

WWF (2010) Living Planet Report 2010. Biodiversity, biocapacity and development. Gland: WWF International.

Young, J. (2003) ‘Green-Collar Workers', Sierra Magazine, July/August 2003.

Zadek, S. (2001) The Civil Corporation. The New Economy of Corporate Citizenship. London: Earthscan. 